\title{
The propagation velocity of seismic activity migrating along the directions of the geodynamic forces prevailing in the northeastern Baikal rift system, Russia
}

\author{
Anna V. Novopashina*, Olga F. Lukhneva \\ Institute of the Earth's Crust, Siberian Branch of RAS, Irkutsk 664033, Russia
}

Article history: received March 4, 2021; accepted May 27, 2021

\begin{abstract}
The recent tectonic stress field in the northeastern Baikal rift system (BRS) corresponds to the crustal deformation field. The stress-strain state of the Earth's crust determines the fault network geometry and spatiotemporal structure of the epicentral field characterized by many earthquake swarms and earthquake migrations in the study area. In order to study the seismic process dynamics in different directions of the crustal deformation, the spatiotemporal analysis of earthquake time series has been made over the 1964-2015 instrumental period. To determine the relationship between crustal stress and spatiotemporal features of the epicentral field the seismic data were projected along horizontal stress tensor axes $\sigma_{3}$ and $\sigma_{2}$, consistent with major directions of the crustal deformation, a strike of major rifting structures, and a general azimuth of active fault groups. The NE-SW direction along the intermediate horizontal stress axes and main faulted arears exhibits slow earthquake migrations up to $60 \mathrm{~km}$ long, propagating with a modal velocity of about 30 kilometers per year. The NW-SE direction along the principal horizontal stress axes, orthogonal to the main faulted areas, is characterized by shorter migration sequences of less duration, propagating with a higher velocity than sequences registered in the NE-SW. The difference between the migration dynamics in mutually orthogonal directions can be attributed to the fault network configuration and the differences in the deformation process.
\end{abstract}

Keywords: The Baikal rift; Migration of seismicity; Deformation; Active fault; Earthquake swarm.

\section{Introduction}

The direction of tectonic forces causing the lithosphere plate motions determines the deformation distribution pattern in the Baikal rift system (BRS). The study area in the northeastern BRS, including the Barguzin, Amut, Kitchera, Upper Angara, Muyakan, Tsipa-Baunt and Western Muya grabens, is dominated by the extensional geodynamic environment with the secondarily-important shear deformation regime [Petit et al., 1996; San'kov et al., 2011]. This environment is characterized by the predominance of the NW-SE crustal extension over the NE-SW deformations which occur in the tensile stress field along the minimum horizontal compression axes [Misharina et 


\section{Anna V. Novopashina et al.}

al., 1975; Nikolaev et al., 1975; San'kov et al., 2000; Lukhnev et al., 2013]. Of secondary importance is the NE-SW crustal shortening along the maximum horizontal compression axes, largely oriented parallel to the main faulted areas. The GPS observations in the Baikal geodynamic test site [Lukhnev et al., 2010; 2013; Lukhneva et al., 2016; Dembelov et al., 2018] showed the southeastward increase in the average horizontal movement rate from $3.0 \mathrm{~mm}$ per year ${ }^{-1}$ in the northern South Baikal basin to $6.5 \mathrm{~mm}$ per year ${ }^{-1}$ in the Barguzin basin. The morphotectonic analysis showed that the recent horizontal movement rates in the northeastern BRS vary from 0.55 to $1.31 \mathrm{~mm}$ per year [San'kov et al., 2000]. The area near the Barguzin basin is characterized by high-rate relative horizontal deformations, which are also typical for the central BRS [Lukhnev et al., 2013].

Recent seismicity is the main indicator of active deformations occurring during the present stage of rifting. The epicentral field structure reflects the geometry of the fault network. The study area in the northeastern BRS is characterized by a high fault density and a large number of earthquakes and earthquake swarms. The area under investigation also shows seismicity migrations which are confined to the most heavily fractured zones [Novopashina and Kuz'mina, 2019] and accompany the deformation front propagation in the fractured area. The migration implies time-and-space-ordered occurrence of earthquake clusters in seismoactive zones.

The ordered series recur in the same locations during the seismic activation periods [Novopashina and Lukhneva, 2020]. One of the most widely held hypotheses of the migration origin is the elastic and elastoplastic stress transfer mechanisms with participation of the upper mantle layers at the fault interaction [e.g.: Chéry et al., 2001; Pollitz et al., 2003; Lin and Stein, 2004; Grapes and Holdgateb, 2014; Tung and Masterlark, 2018]. Some of researchers relate the occurrence of the ordered earthquake series to the formation of the lithospheric deformation waves of different length [Gorbunova and Sherman, 2012; Sherman, 2013, 2014; Bornyakov et al., 2014; Novopashnina and San'kov, 2015; Vikulin et al., 2016; Trofimenko et al., 2017; Bykov, 2018; Žalohar, 2018; Bykov and Merkulova, 2020]. The velocity of migration depends on the stress transfer mechanism. The BRS is characterized by a wide scatter of different-scale migration velocities: from several kilometers to several hundred kilometers per year [Gorbunova and Sherman, 2012; Sherman, 2013, 2014; Bornyakov et al., 2014; Levina and Ruzhich, 2015; Ruzhich et al., 2016; Kakourova and Klyuchevskii, 2017; Bykov, 2018; Klyuchevskii and Kakourova, 2018; Novopashina and San'kov, 2015; Novopashina and Sankov, 2018].

The order of priority for fault activation occurs mainly in low-seismicity distribution, and rare large events and earthquake swarms - triggers or results of migration - are at the ends of migration chains corresponding to the fracture-zone boundaries. Most of the ordered earthquake series are recorded along the strike of faulted areas, with some of them observed across the strike of parallel fault systems [Novopashnina and Sankov, 2018]. Formerly, the migrations propagating at a velocity from a few of kilometers to tens of kilometers per year were recorded in the central and northeastern BRS along the major rifting structures and a general direction of fault groups [Novopashnina and Sankov, 2018; Novopashina and Lukhneva, 2020]. Other directions for research of spatiotemporal characteristics of seismicity were not considered in detail. The present paper focuses on the comparison between migrations of seismic activity along the mutually orthogonal horizontal axes of the principal and intermediate stresses in earthquake sources ( $\sigma_{3}$ and $\sigma_{2}$, respectively). Presented herein are the results of visualization of spatiotemporal distribution of the total seismic energy for detailed zones of seismic data projections co-directional with the horizontal stress $\sigma_{3}$ and $\sigma_{2}$ from published sources [Petit et al., 1996].

\subsection{Geological settings}

The Baikal continental rift system more, than $1500 \mathrm{~km}$ in length, is represented by a series of horsts and grabens formed at the boundary between the stable northern Eurasian plate and the Amur microplate moving eastward at a rate of a few millimeters per year [San'kov et al., 2000] (Figure 1). The process of extension which began in the Late Cretaceous [Logachev, 2003] or Paleocene-Oligocene [San'kov et al., 2000] with the initiation of the most ancient South Baikal basin continued in the Late Eocene with formation of the North Baikal, Kitchera and Barguzin basins and then in the Pliocene and Quaternary, gradually involving the flank areas [Logachev, 2003].

The cause of extension is a subject of debate. Some researchers follow the hypothesis of active rifting caused by the plume inferred beneath the BRS [Logatchev, 1984; Logachev, 2003; Zorin et al., 2003; Turutanov, 2018]. Some support the mechanism of passive rifting in which the divergence occurs due to the plate motion related to the Indo-Eurasian collision [Tapponnier and Molnar, 1979; Zonenshain and Savostin, 1981; Thybo and Nielsen, 2009]. 
And the others allow for the possibility of both mechanisms of extension. In particular, Mats [2012] supposed that the passive rifting model corresponds the early (Late Cretaceous, Paleocene and Early Eocene) and middle (Middle Eocene) stages of rifting, and the active model - to the present stage which lasts since the Late Pliocene (3.5 million years ago).

Beneath the study area there is a large amount of uplift of the asthenosphere roof - up to $70-80 \mathrm{~km}$ - [Petit and Déverchère, 2006] as compared to that on the platform where the lithospheric thickness reaches 100-260 km [Mordvinova et al., 2016]. Beneath the basins there also appears to be crustal thinning to 30-35 km [Sherman et al., 1992] as compared to the uplifts where the Moho boundary can be identified at depths of $40-45 \mathrm{~km}$ [Zorin et al., 2003]. The average depth to the base of the brittle layer is 30-35 km [Petit et al., 2008]. The hypocenter depths are estimated at up to $50 \mathrm{~km}$, with most of them - at 10-30 km [Radziminovich, 2010].

The period of the Late Cenozoic activation is related to the rejuvenation of ancient faults that strike primarily $\mathrm{NE}-\mathrm{SW}$ and $\mathrm{E}-\mathrm{W}$. A combination of disjunctives of various kinematic types results from the regional tectonic NWSE extension and NE-SW compression. The central rift zone is characterized by the regime of horizontal crustal movements with a tensile stress field. The areas of horizontal crustal movements with shear stress field dominate in the southwestern flank and take place in the northeastern flank of the Baikal rift zone. The study area of the northeastern BRS is represented by a complex of predominant NE-SW faults which are normal, less frequently, oblique slip and left-lateral strike-slip faults, and secondary NW-SE oriented faults, most of which are right-lateral strike-slip [Lukhnev et al., 2013]. The main rift-forming faults, bordering the Barguzin, Kitchera, Upper Angara, Muyakan, Muya and Tsipa-Baunt northeastern rift basins, are NE-SW or N-S oriented normal faults [Jolivet et al., 2013]. There are angular differences between the directions of the Holocene movements (Figure 1a) and those of the minimum horizontal compressive (tensile) stress $\sigma_{3}$ (Figure 1b), which are attributed to the lithosphere block rotation [San'kov et al., 2000].

\section{Data and methods}

\subsection{Technique of seismic activity migration detection}

The spatiotemporal development of seismic process is studied with spatiotemporal diagrams plotted for seismic data projection zones. A projection zone is specified by the following parameters: center point coordinates, length $(\mathrm{L})$, width (W), and strike azimuth (Az) of symmetry axis Ax. Seismic energy released over a month is summed up in cells of length $\Delta \mathrm{L}=0.1^{\circ}$ and projected on the symmetry axis of a projection zone. Logarithm of the total seismic energy (parameter $\operatorname{Lg} \mathrm{E}_{\text {sum }}$ ) is used for plotting three-dimensional spatiotemporal diagrams. In each unit cell the energy was calculated as: $\operatorname{Lg} E_{\text {sum }}=\lg \left(\sum E_{n}\right)$, when $n$ - number of earthquakes, $E$ - earthquake energy in Joules: $\operatorname{lgE}=1.5 \mathrm{M}+4.8$ [Richter, 1958; Kanamori, 1977].

In the present paper, spatiotemporal diagrams are plotted over the different time intervals of instrumental period 1964-2015 for magnitudes $2.2 \leq M \leq 3.3$, since seismic migrations are clearly defined within a certain range of small-earthquake energy. The slope of maxima chains $\mathrm{LgE}_{\text {sum }}$ towards the diagram axes reflects the velocity and direction of seismic activity propagation. The velocity of the migration process is determined as a ratio of distance projection (in kilometers) to time projection (in years). The most representative series with a high spatiotemporal correlation coefficient were distinguished. The migration velocity determination error is about $5 \mathrm{~km}$ per year. The most complete description of the projection technique is presented in Novopashina and Lukhneva [2020].

\subsection{Locations of seismic-data projection zones}

Previously, in the northeastern BRS on the segments of high density of the faults which are intense crustal deformation zones, we have noticed the NE-SW migration of seismic activity (Figure 1c) along the strike of major rift-forming structures [Novopashina and Sankov, 2018; Novopashina and Lukhneva, 2020]. The migration occurrences were observed between the Amut and Barguzin basins, in the areas of the Kitchera and Upper Angara basins, and near the North Muya range and Muyakan basin. In order to compare specific features of orthogonal seismicity propagation with more detailed locations of migration, the present paper deals with seismic-data 


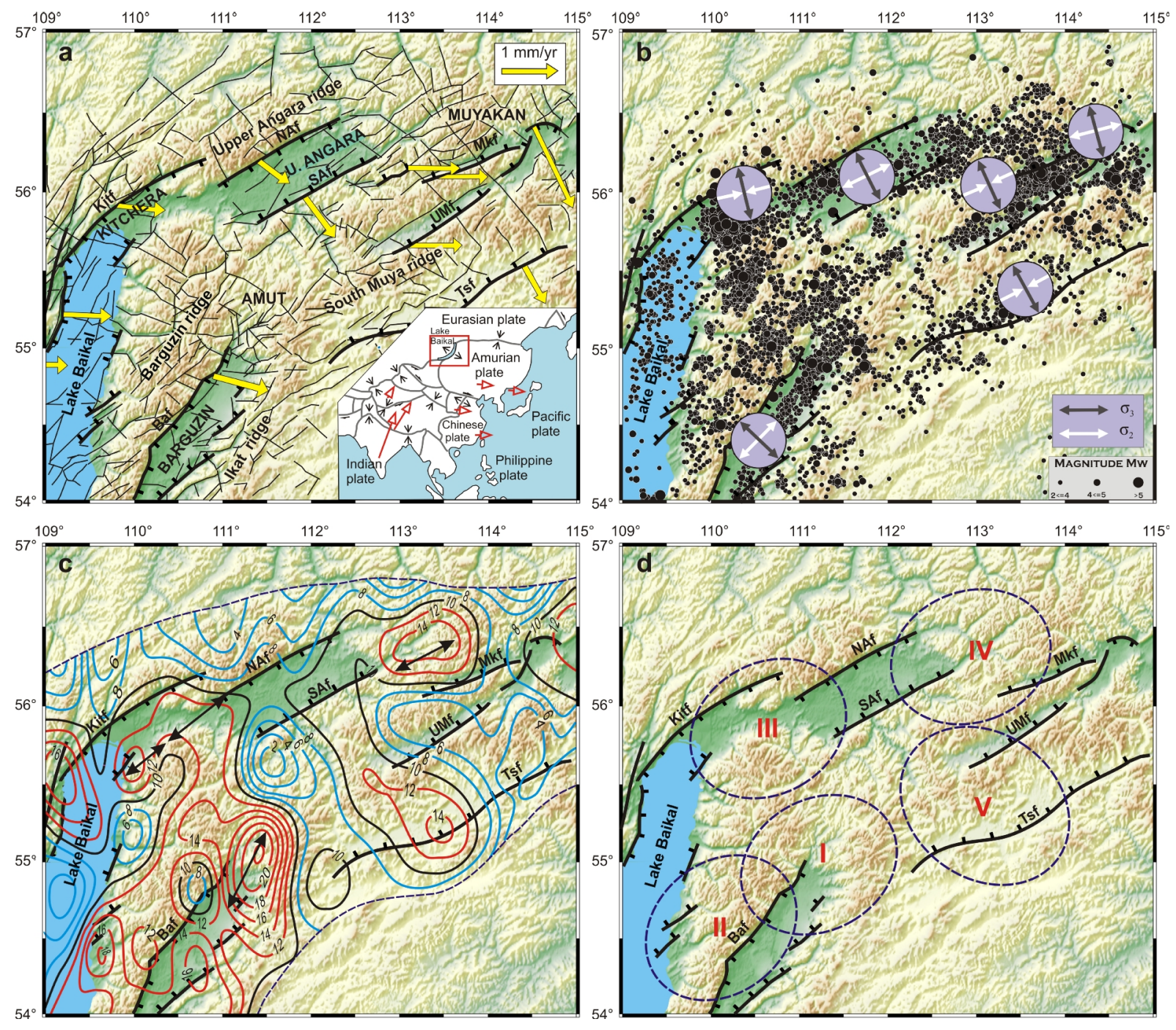

Figure 1. Scheme of the northeastern BRS: a - Geographical and geodynamic features of the study area: black bold lines show the main normal rift-forming faults [Jolivet et al., 2013] with fault names (Baf - Barguzin, Kitf - Kitchera, NAf - North Upper Angara, SAf - South Upper Angara, Mkf - Muyakan, UMf - Upper Muya, Tsf - Tsipican), yellow arrows show the directions and rates of Holocene motions [San'kov et al., 2000]. In the inset map the study area is shown in the global tectonic scheme [Thybo and Nielsen, 2009], where red arrows show GPS measurements of plate motion, black arrows show relative displacement at plate boundaries; $b$ - contemporary mid-crustal stress state from the data of earthquake focal mechanisms: horizontal stress axes $\sigma_{3}$ are shown by divergent gray arrows, the intermediate horizontal stress axes $\sigma_{2}$ by white arrows (white divergent arrows indicate radial extension, white convergent arrows indicate uniaxial extension [Petit et al., 1996], black circles show the epicenters over the instrumental period 1994-2015 of the hypocenter depth up to $50 \mathrm{~km}$, mostly 10$30 \mathrm{~km}$ [Radziminovich, 2010]; c - active fault density: the contour line values show the number of faults in cell $0.37^{*} 0.37^{\circ}$ [Novopashina and Kuz'mina, 2019], black arrows show seismic migrations obtained previously from Novopashina and Lukhneva [2020]; d - areas of plotting rose-diagrams and study of the dynamics of seismic process (dashed lines) with their numbers (Roman). 
projection areas oriented along the horizontal tensile stress axes $\sigma_{3}$, sub-perpendicular to the major rifting structures, and along the intermediate stress axes $\sigma_{2}$, co-directional with the major fault strike. The study involves stress tensor main axis $\sigma_{3}$ and $\sigma_{2}$ (intermediate) (see Figure 1b) reported in [Petit et al., 1996; San'kov et al., 2011], which were obtained from the seismological data. In order to refine approximation of faults along strike azimuth $\sigma_{2}$, directions $\sigma_{2}$ have been preliminarily compared to the average strike of major rift-forming faults from Lunina [2016], general fault strike displayed on rose-diagrams and rupture plane orientations presented in [Sankov and Dobrynina, 2015]. The rose-diagrams (Figure 2) have been plotted with the analysis of fault strikes from the database Lunina [2016] for the most heavily fractured areas shown in Figure 1d. The projection zones, where the seismic data are acquired, cover the linearly elongated concentrations of epicenters of earthquakes of different intensities (Figure 3a, 3b). The selection of the centers of seismic-energy projection zones is determined by the location of the previously observed regular occurrence of seismic migration (Figure 1c).

\section{Results}

\subsection{The comparison between the geological-structural and seismological data}

Table 1 summarizes data on the present-day geodynamic environment of the northeastern BRS from published sources: direction of the axes of intermediate stresses $\sigma_{2}$ from [Petit et al., 1996], strike of the major rift-forming faults from [Lunina, 2016], general orientations of fault groups on the rose-diagrams (Figure 2), and rupture-plane orientations from Sankov and Dobrynina [2015]. The distribution of faults on the rose-diagrams for zones I-V of the northeastern BRS testifies the predominance of the forces producing NW-SE crustal deformations and the effect of secondary forces conducive to NE-SW deformations.

\begin{tabular}{|c|c|c|c|c|c|}
\hline $\begin{array}{l}\text { Number of } \\
\text { a rose-diagram } \\
\text { plotting area } \\
\text { (Figure 1d) }\end{array}$ & Main faults & $\begin{array}{l}\text { Azimuths of } \\
\text { intermediate } \\
\text { stress axes } \sigma_{2}\end{array}$ & $\begin{array}{c}\text { Strike of } \\
\text { the main } \\
\text { faults (degrees) }\end{array}$ & $\begin{array}{l}\text { Strike range of } \\
\text { fault groups in } \\
\text { the rose plot in } \\
\text { Figure } 2 \\
\text { (degrees) }\end{array}$ & $\begin{array}{l}\text { Orientation } \\
\text { range of } \\
\text { rupture planes }\end{array}$ \\
\hline Reference & $\begin{array}{l}\text { Petit et al. } \\
\text { [1996] }\end{array}$ & $\begin{array}{l}\text { Petit et al. } \\
\text { [1996] }\end{array}$ & $\begin{array}{l}\text { Lunina } \\
\text { [2016] }\end{array}$ & & $\begin{array}{c}\text { Sankov and } \\
\text { Dobrynina [2015] }\end{array}$ \\
\hline I & $\begin{array}{l}\text { Faults of } \\
\text { fractured } \\
\text { intrabasin } \\
\text { separating the } \\
\text { Amut and } \\
\text { Barguzin } \\
\text { basins }\end{array}$ & - & $\begin{array}{c}52,52,53,59 \\
78,78,84,86 \\
\text { (mean value } 68 \text { ) }\end{array}$ & $50-60$ & - \\
\hline II & Barguzin & $41 \pm 3$ & $\begin{array}{c}53,35,25 \\
29,57,47 \\
\text { (mean value } 41 \text { ) }\end{array}$ & $40-50$ & $42-47$ \\
\hline \multirow{3}{*}{ III } & $\begin{array}{l}\text { North Upper } \\
\text { Angara }\end{array}$ & $62 \pm 3$ & 63 & $70-80$ & $72-77$ \\
\hline & $\begin{array}{l}\text { South Upper } \\
\text { Angara }\end{array}$ & - & 65 & $70-80$ & - \\
\hline & Kitchera & $73 \pm 3$ & $65,75,60$ & $70-80$ & $62-67$ \\
\hline IV & Muyakan & $68.1 \pm 1$ & 60 & $50-60,70-80$ & $74-79$ \\
\hline $\mathrm{V}$ & Tsipican & $61 \pm 5$ & 60,65 & $60-70$ & $32-72$ \\
\hline
\end{tabular}

Table 1. Geodynamic parameters of active structures in the northeastern BRS. 


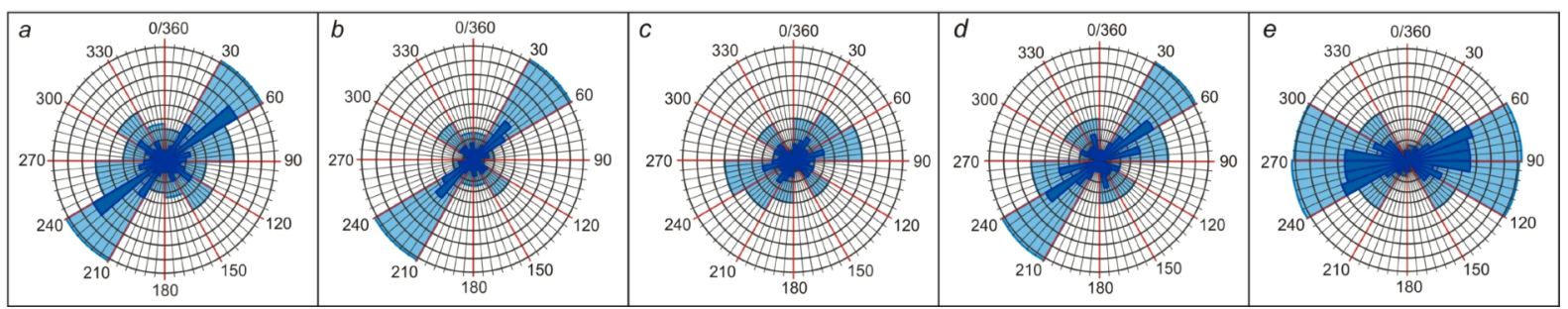

Figure 2. Azimuthal rose-diagrams of active faults in the northeastern BRS for areas I-V in Figure 1d: $a-$ area I, b - area II, c - area III, $\mathrm{d}$ - area IV, e - area V, blue color stands for the number of faults in $10^{\circ}$ sectors, light-blue color for that in $30^{\circ}$ sectors. Fault data from Lunina [2016].

The comparison between the geological-structural and seismological data (Table 1) shows the deviation 1-13 ${ }^{\circ}$ occurring between the intermediate stress axes $\sigma_{2}$ (column 3) and the orientation of major ruptures (column 4 in Table 1), and the deviation of $\sigma_{2}$ from the general direction of seismoactive faults - from the rose-diagram data (column 5 in Table 1) - structures (Figure 2) does not exceed $8^{\circ}$. The difference between $\sigma_{2}$ and the orientation of rupture planes in earthquake sources (column 6 in Table 1), reflecting the strike of the most active faults in the instrumental period, varies within $10^{\circ}$.

Thus, the values for $\sigma_{2}$ azimuths, used for constructing seismic-data projection zones, approximate the general directions of fault groups (Figure 2), including those most active in the instrumental period, most accurately and somewhat deviate from the major fault strikes.

\subsection{Analysis of the seismic process dynamics}

In order to identify development trends of seismic process towards crustal deformations, spatiotemporal diagrams were plotted for the logarithm of the total seismic energy $\left(\operatorname{LgE}_{\text {sum }}\right)$, released in the seismic-data projection zones. Spatial axes of the projection zones are oriented along the principal horizontal stress axes $\sigma_{3}$ and $\sigma_{2}$ (Figure 3 , Table 2,3). The strike of spatial axes of seismic data projection, derived according to azimuth $\sigma_{2}$, is consistent with the major strike of active faults, and the direction of projection axes along $\sigma_{3}$ corresponds to the orthogonal position.

\begin{tabular}{cccccc} 
Zone number & \multicolumn{2}{c}{$\begin{array}{c}\text { Center coordinates } \\
\text { (degrees) }\end{array}$} & $\begin{array}{c}\text { Azimuth of symmetry } \\
\text { axis (degrees) }\end{array}$ & $\begin{array}{c}\text { Length } \\
\mathbf{( k m )}\end{array}$ & $\begin{array}{c}\text { Width } \\
\mathbf{( k m )}\end{array}$ \\
Longitude & Latitude & 331 & 187 & 144 \\
\hline Ia & 111.58 & 55.37 & 131 & 155 & 122 \\
\hline IIa & 110.03 & 54.64 & 337 & 190 & 134 \\
\hline IIIa & 111.20 & 55.64 & 338 & 184 & 145 \\
\hline IVa & 113.15 & 56.18 & 164 & 133 & 178 \\
\hline Va & 113.50 & 55.30 & & & \\
\hline
\end{tabular}

Table 2. Parameters of seismic-data projection zones oriented along the stress axes $\sigma_{3}$.

Figure 3a and Figure 4a show projection zones Ia, IIa, IIIa, IVa and Va, corresponding to the directions of principal horizontal stress axes $\sigma_{3}$ (Table 2). Figure $3 \mathrm{~b}$ and Figure $4 \mathrm{~b}$ show zones $\mathrm{Ib}$, IIb, IIIb, IVb and $\mathrm{Vb}$, corresponding to the directions of intermediate horizontal stress axes $\sigma_{2}$ (Table 3). Since the spatial structure of epicentral field is characterized by certain NE-SW linearly elongated earthquake epicenter concentrations, the data analysis in the 
areas corresponding to $\sigma_{3}$ allows considering seismic process across the system of subparallel epicenter concentrations, and that in the areas corresponding to $\sigma_{2}$ - along the linearly elongated concentrations. The direction of observed occurrences of migration of seismic activity is shown by arrows in Figure 4 . The names of the swarms are shown in Table 4.

\begin{tabular}{cccccc} 
Zone number & \multicolumn{2}{c}{$\begin{array}{c}\text { Center coordinates, } \\
\text { (degrees) }\end{array}$} & $\begin{array}{c}\text { Azimuth of symmetry } \\
\text { axis (degrees) }\end{array}$ & $\begin{array}{c}\text { Length } \\
\text { (km) }\end{array}$ & $\begin{array}{c}\text { Width } \\
\text { (km) }\end{array}$ \\
& Longitude & Latitude & 61 & 145 & 111 \\
\hline $\mathrm{Ib}$ & 111.58 & 55.37 & 41 & 167 & 158 \\
\hline $\mathrm{IIb}$ & 110.03 & 54.64 & 65 & 176 & 134 \\
\hline $\mathrm{IIIb}$ & 111.20 & 55.64 & 68 & 187 & 131 \\
\hline $\mathrm{IVb}$ & 113.15 & 56.18 & 61 & 140 & 122 \\
\hline $\mathrm{Vb}$ & 113.50 & 55.30 & & & \\
\hline
\end{tabular}

Table 3. Parameters of seismic-data projection zones oriented along the intermediate stress axes $\sigma_{2}$.

\begin{tabular}{ccccc} 
Number & Years & Sequence name & M $_{\text {Wmax }}$ & Reference \\
\hline 1 & $1962-1969$ & Ikat swarm & 4.4 & $\mathrm{a}$ \\
\hline 2 & $1966-1967$ & Kumora swarm & 5 & $\mathrm{a}$ \\
\hline 3 & 1968 & Bountov sequence & 5 & $\mathrm{a}$ \\
\hline 4 & 1969 & Barguzin swarm & 3.9 & $\mathrm{a}$ \\
\hline 5 & 1969 & Bauntov swarm & 3.9 & $\mathrm{a}$ \\
\hline 6 & 1971 & Verhnetompudin swarm & 3.9 & $\mathrm{a}$ \\
\hline 7 & $1973-1974$ & Tsipican swarm & 5 & $\mathrm{a}$ \\
\hline 8 & 1975 & Srednetompudin swarm & 3.9 & $\mathrm{a}$ \\
\hline 9 & 1976 & 1-Uoyan sequence & $>5.5$ & $\mathrm{a}$ \\
\hline 10 & $1976-1978$ & Svetlin swarm & 5 & $\mathrm{a}$ \\
\hline 11 & 1978 & Uakit swarm & 4.4 & $\mathrm{a}$ \\
\hline 12 & 1979 & Gorbylok swarm & 3.9 & $\mathrm{a}$ \\
\hline 13 & $1979-1981$ & Amut swarm & 5 & $\mathrm{a}$ \\
\hline 14 & $1979-1983$ & Angarakan swarm & $2 * 4.4$ & $\mathrm{a}$ \\
\hline 15 & $1981-1982$ & Amundin cluster & 3.9 & $\mathrm{a}$ \\
\hline 16 & 1995 & Upper-Muya sequence & 5.9 & $\mathrm{~b}$ \\
\hline 17 & 1999 & Kitchera swarm & $6.0,5.6$ & $\mathrm{c}$ \\
\hline 18 & 2002 & Kovilin cluster & $4.7,4.6$ & $\mathrm{~d}$ \\
\hline 19 & 2003 & Kumora cluster & 5.6 & $\mathrm{e}$ \\
\hline 20 & 2003 & Ulugnin cluster & 4.6 & $\mathrm{~d}$ \\
\hline 21 & 2006 & Kitchera-Akulikan cluster & 5.2 & $\mathrm{~d}$ \\
\hline 22 & 2007 & Uompudin cluster & 5.4 & $\mathrm{f}$ \\
\hline 23 & $2014-2016$ & $>5.5$ & $\mathrm{~g}$ \\
\hline
\end{tabular}

References: a) Solonenko and Solonenko, 1987; b) Radziminovich et al., 2013; c) Melnikova et al., 2007; d) Mel'nikova et al., 2020; e) Radziminovich et al., 2009; f) Gileva et al., 2013; g) The Baikal Regional Seismological Center of the Geophysical Survey RAS.

Table 4. Data on swarms, sequences and clusters of the earthquakes with magnitude $M \geq 3.9$ over the instrumental period 1962-2015. 
Anna V. Novopashina et al.
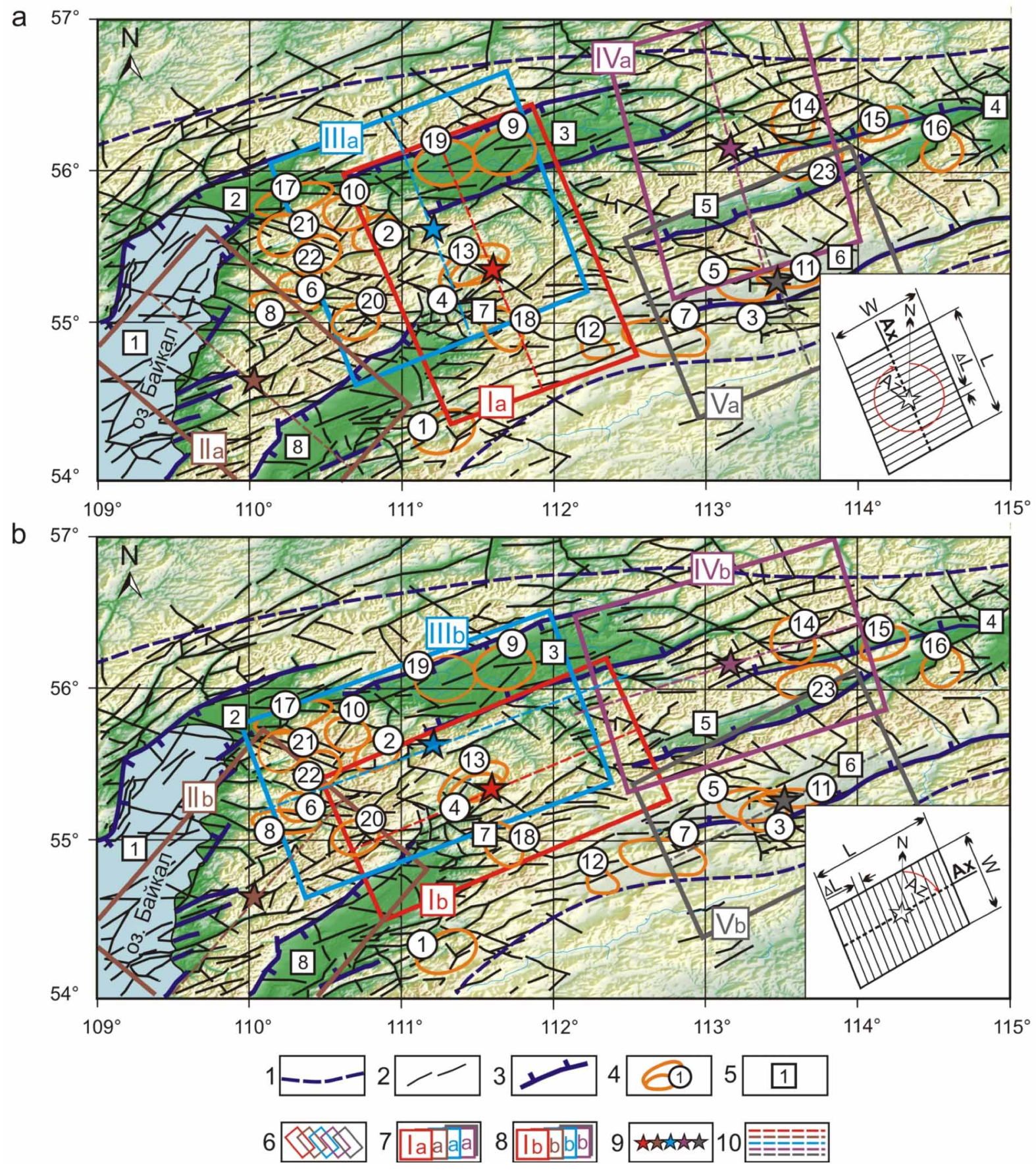

Figure 3. Seismic-data projection areas in the northeastern BRS corresponding to the directions of principal horizontal stress axes: $\mathrm{a}$ - areas oriented according to the orientation of $\sigma_{3}, \mathrm{~b}$ - areas oriented according to the orientation of $\sigma_{2} .1$ - boundary of the BRS; 2 - active faults [Lunina, 2016]; 3 - main faults [Petit and Déverchère, 2006]; 4 - large earthquake series and earthquake swarms including the events with $M>3.9$ (with numbers and names presented in Table 4); 5 - basin numbers (1 - North Baikal, 2 - Kitchera, 3 - Upper Angara, 4 - Muya, 5 - Muyakan, 6 - Tsipa-Baunt, 7 - Amut, 8 - Barguzin); 6 - seismic-data projection zones (I-V); 7 - numbers of seismic-data projection zones oriented according to the orientation of $\sigma_{3}, 8$ - numbers of seismic-data projection zones oriented according to the orientation of $\sigma_{2}, 9$ - centers of projection zones; 10 - spatial axes Ax of projection zones. Center and zone contour for each polygon are same-colored. The sidebars show a scheme of spatial orientation of projection zones: $\mathrm{L}$ - zone length, $\mathrm{W}$ - zone width, $\Delta \mathrm{L}$ - size of a cell for calculation of total energy $\operatorname{LgE}_{\text {sum }}, \mathrm{Ax}$ - spatial zone axis, Az - azimuth of axis Ax. 
Figure 5 presents spatiotemporal diagrams for the projection areas corresponding to $\sigma_{3}$ orientation. The diagram in Figure 5a for projection zone Ia (Figure 3a, 4a), covering different time intervals throughout the instrumental period, exhibits multiple migration series propagating from the Amut-area swarm 1979-1981 (red arrows in Figure 4a, 5a) at velocities of 25-35 km per year for 30-50 km to SE and the opposite NW directions (Table 5). The upper part of the diagram, corresponding to the Upper Angara basin, shows 40-50 km long migration chains in the period 1977-1987.

The diagram in Figure $5 \mathrm{~b}$ for projection area IIa (Figure $3 \mathrm{a}, 4 \mathrm{a}$ ), occasionally shows rare and short-time migration series with a length of 30-40 km and a velocity of $45-50 \mathrm{~km}$ per year, from the projection zone center towards the Barguzin basin and within concentrations in proper basin in the direction sub-perpendicular to the Barguzin fault. There is also observed a discrete series with a length of about $50 \mathrm{~km}$ and a velocity of about $30 \mathrm{~km}$ per year (Table 5), from the mid-Barguzin basin to the 1975 Srednetompydin-area swarm (brown arrows in Figure 4a, 5b).

The diagram in Figure 5c for projection area IIIa (Figure 3a, 4a) shows multiple migration chains of the Amutarea swarm with a length of up to $50 \mathrm{~km}$ and a velocity of up to $50 \mathrm{~km}$ per year (Table 5). Recurring episodes of migration with a velocity of about $30 \mathrm{~km}$ per year are also registered in the area of the 1976 1-Uayan series, 19761978 Svetlin swarm, 2003 Kumora cluster, and in the 1999 Kitchera-area swarm (blue arrows in Figure 4a, 5c).

Figure 5d shows a diagram for zone IVa (Figure 3a, 4a) covering the area of 1979-1983 Angarakan swarm and 2014-2016 Upper Muya sequence (violet arrows in Figure 4a, 5d). The migration series with a length of $20-40 \mathrm{~km}$ and a velocity of $15-50 \mathrm{~km}$ per year are appeared in the swarm activity areas and their separation zones (Table 5).

Figure 5e for area Va (Figure 3a, 4a) exhibits an intensive migration process in the projection for the Baunt, Tsipikan and Uakit swarms (grey arrows in Figure 4a, 5e). The velocity of numerous chains of different lengths (15$45 \mathrm{~km}$ ) whose propagation time is $0.7-2.5$ years varies from 10 to $30 \mathrm{~km}$ per year (Table 5). The diagram (upper sector in Figure 5e) also depicts elongated (up to $45 \mathrm{~km}$ ) and long-time (up to 4 years) earthquake series between the Tsipikan fault, related to the projection for the Baunt, Tsipikan and Uakit swarms, and Muyakan fault zone, related to the Upper Muya sequence projection.

Therefore, the analysis of diagrams plotted for the zones co-directional to axes $\sigma_{3}$ shows that the migration series occur across the strike of major rifting structures along the axes of elongation of the Earth's crust. The length of the revealed migration series varies from 15 to $50 \mathrm{~km}$. The propagation time of migrations rarely exceeds 1 year which may be due to migration propagation along the short fault structures. Average migration velocity is $20-40$ $\mathrm{km}$ per year in NW-SE direction.

Figure 6 presents diagrams for the projection zones corresponding to the directions of $\sigma_{2}$. The diagram in Figure 6a, for projection zone $\mathrm{Ib}$ (Figure $3 \mathrm{~b}, 4 \mathrm{~b}$ ), illustrates numerous migration chains with a length of 30-60 km propagating from the Amut-area swarm to the Barguzin basin and back (red arrows in Figure 4b, 6a and dashed ellipses in the sidebar of Figure 6a). The slope angle of chains corresponds to velocities of 10-30 km per year (Table 5).

\begin{tabular}{ccccc} 
Zone number & \multicolumn{2}{c}{$\begin{array}{c}\text { Chain length } \\
(\mathbf{k m})\end{array}$} & a & \multicolumn{2}{c}{$\begin{array}{c}\text { Migration velocity } \\
\text { (km/year) }\end{array}$} \\
& a & $30-60$ & $25-35$ & b \\
\hline I & $30-50$ & $55-60$ & $30-50$ & $10-30$ \\
\hline II & $30-50$ & $25-60$ & $30-50$ & $15-30$ \\
\hline III & $30-50$ & $30-55$ & $15-50$ & $20-50$ \\
\hline IV & $20-40$ & $40-55$ & $10-30$ & $15-30$ \\
\hline V & $15-45$ & & & $10-25$ \\
\hline
\end{tabular}

Table 5. Characteristics of migrations of seismic activity.

Figure $6 \mathrm{~b}$ for zone IIb (Figure 3b, 4b), shows chains with a length of up to $60 \mathrm{~km}$ whose velocities are $15-30 \mathrm{~km}$ per year in the seismic activation period 1971-1986 in the 1971 Verkhnetompudin-area and 1975 Srednetompudinarea swarms (Table 5) and the chains propagating southwest of the central projection zone and back in the period 1972-1979 (brown arrows in Figure 4b, 6b). 
Anna V. Novopashina et al.
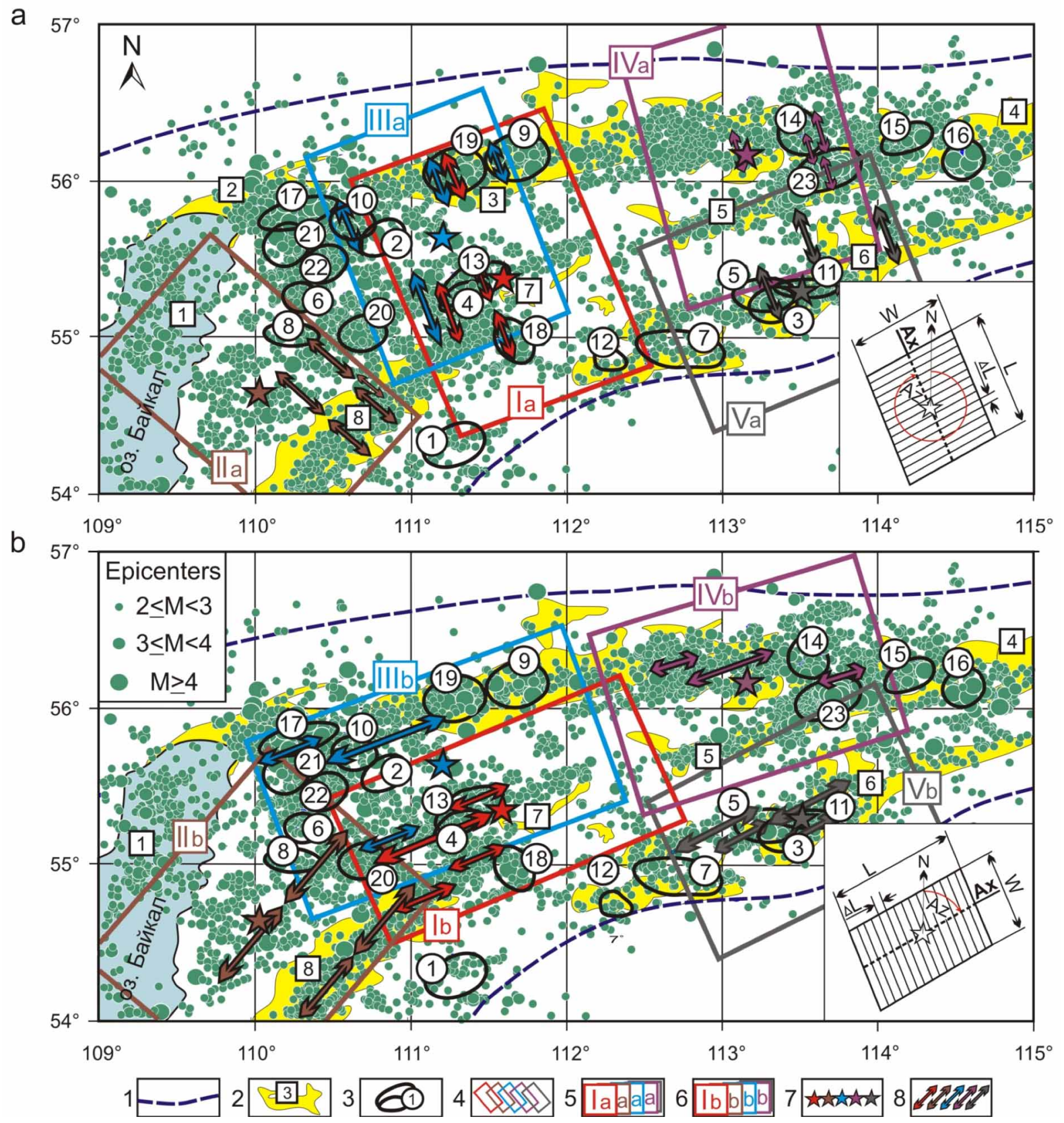

Figure 4. Epicentral field of the northeastern BRS and direction of migration of seismic activity for the total seismic energy projection zones: $\mathrm{a}$ - migrations in direction $\sigma_{3}, \mathrm{~b}$ - migrations in direction $\sigma_{2} .1$ - boundary of the BRS; 2 - basins of the BRS with their numbers (figures in squares: 1 - Baikal, 2 - Kitchera, 3 - Upper Angara, 4 - Muyakan, 5 Muya, 6 - Tsipa-Baunt, 7 - Amut, 8 - Barguzin; 3 - earthquake swarms with their circled numbers (Table 4); 5 numbers of seismic data projection zones corresponding to vectors $\sigma_{3} ; 6$ - numbers of seismic data projection zones corresponding to vectors $\sigma_{2} ; 7$ - centers of projection zones; 8 - direction of migration for seismic activity. Center, zone contour and migration direction for the same polygon are same-colored. The sidebars show a scheme of spatial orientation of projection zones: $\mathrm{L}$ - zone length, $\mathrm{W}$ - zone width, $\Delta \mathrm{L}$ - size of a cell for calculation of total energy - $\mathrm{LgE}_{\text {sum }}, \mathrm{Ax}$ - spatial zone axis, $\mathrm{Az}$ - azimuth of axis Ax. 
a $\mathrm{Ax}$

a
है
$\frac{5}{8}$
$\frac{5}{5}$
$\frac{\pi}{0}$

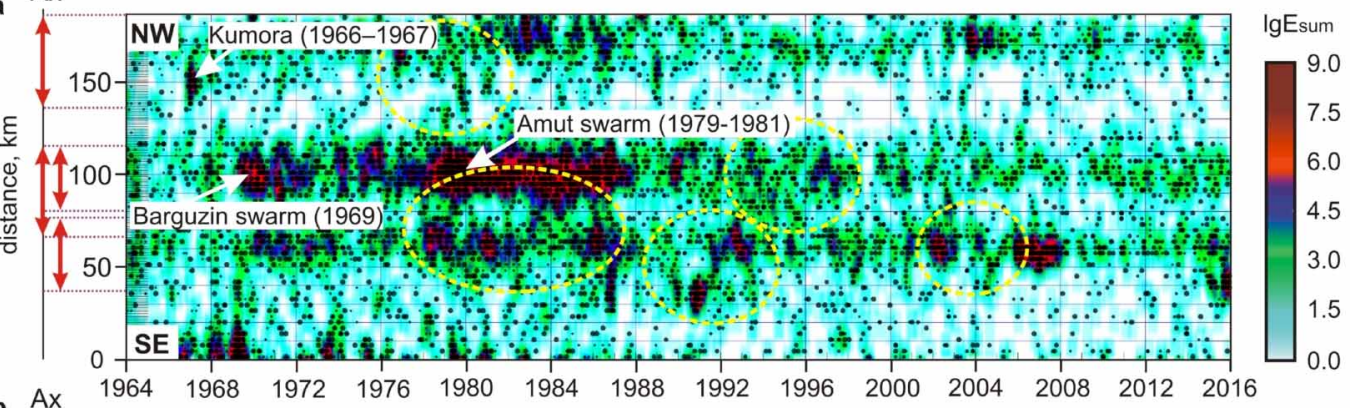

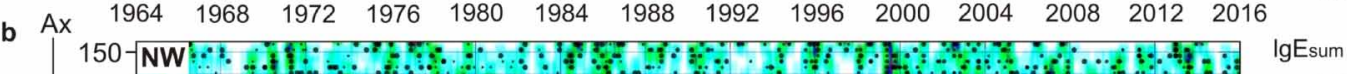
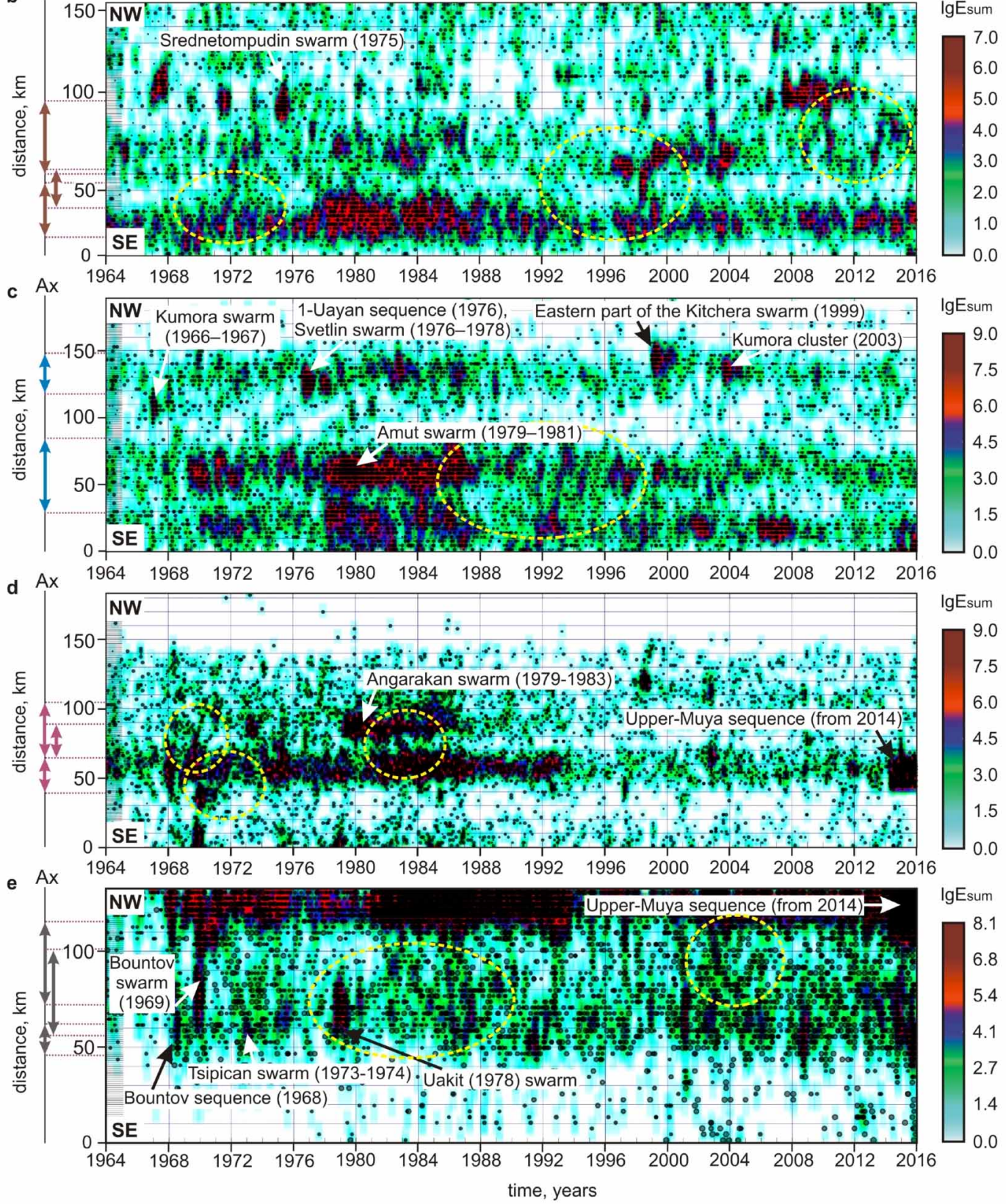

Figure 5. Spatiotemporal diagrams of $\operatorname{LgE}_{\text {sum }}$ for the seismic-energy projection areas corresponding to the $\sigma_{3}$ axes orientation, projected onto the spatial axis Ax of the projection zones: $\mathrm{a}$ - area Ia, b - area IIa, c - area IIIa, $\mathrm{d}$ area IVa, e - area Va. The diagram is plotted by the MathGL program. The graph consists of two layers: the layer of interpolated $\mathrm{LgE}_{\text {sum }}$ values (color) is covered by the layer of seismic event points. Dashed ellipses show some of the noted migration chains mentioned in the text. Colored arrows show the projections of migration chains on the Ax axis respectively Figure $3 \mathrm{a}$ and $4 \mathrm{a}$. 
Anna V. Novopashina et al.

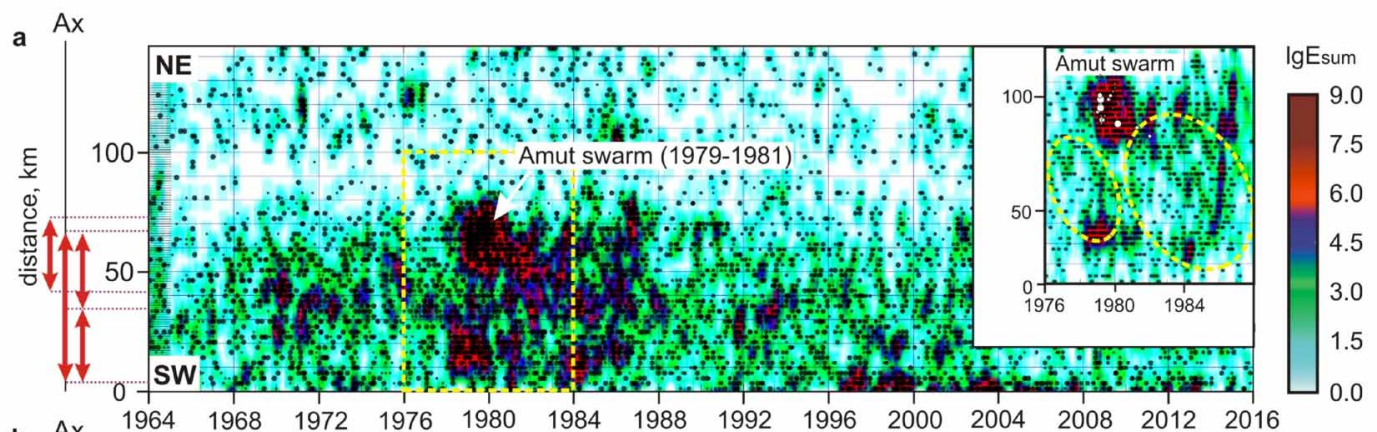

b Ax $\begin{array}{llllllllllllll}1964 & 1968 & 1972 & 1976 & 1980 & 1984 & 1988 & 1992 & 1996 & 2000 & 2004 & 2008 & 2012 & 2016 \\ \text { IgEsum }\end{array}$
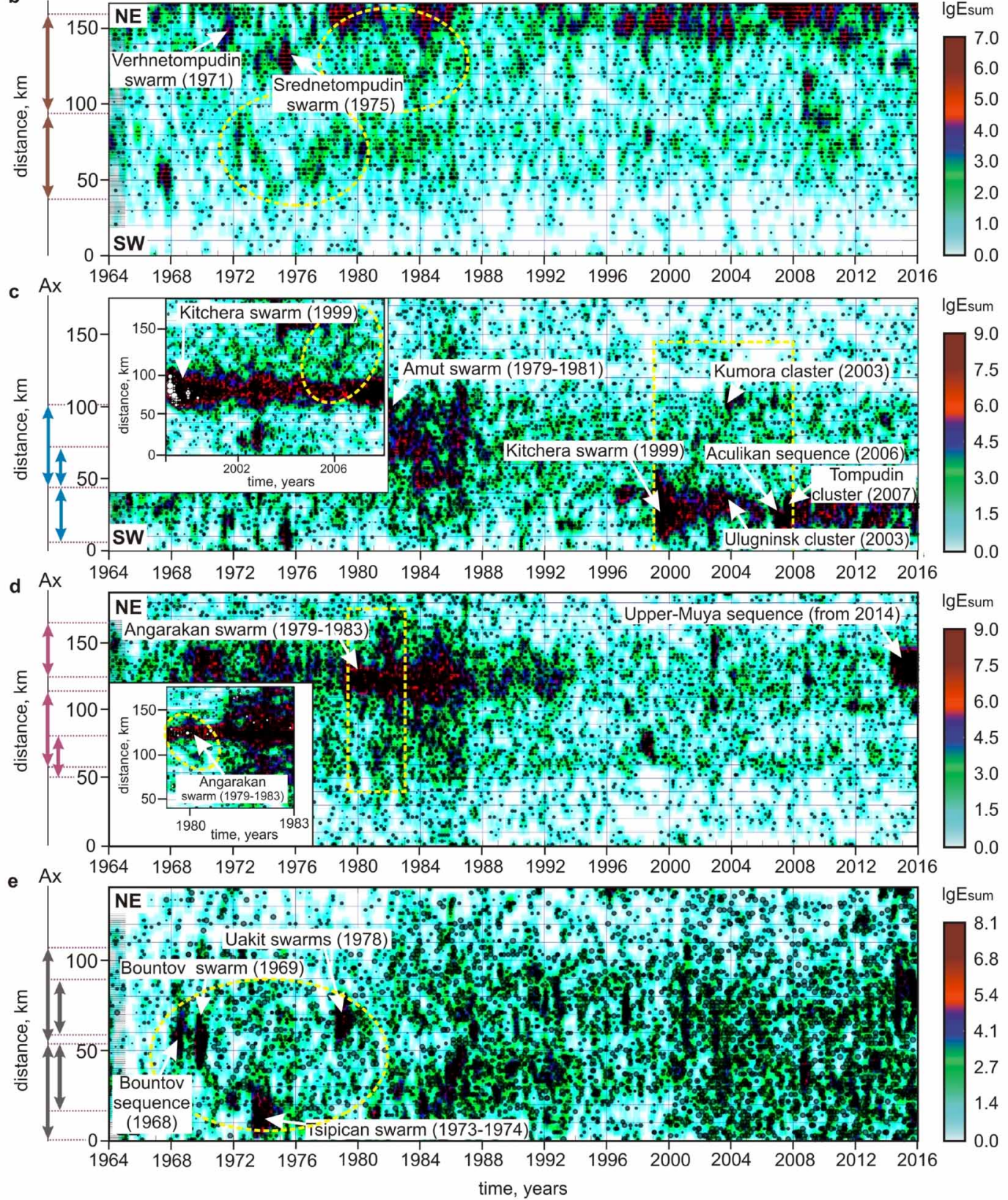

Figure 6. Spatiotemporal diagrams $\mathrm{LgE}_{\text {sum }}$ for seismic-energy projection areas corresponding to the $\sigma_{2}$ axes orientation, projected onto the spatial axis Ax of the projection zones: $\mathrm{a}$ - area Ib, b -area IIb, c -area IIIb, d -area IVb, e -area Vb. The diagram is plotted by the MathGL program. The graph consists of two layers: the layer of interpolated $\mathrm{LgE}_{\text {sum }}$ values (color) is covered by the layer of seismic event points. Dashed ellipses show the migration chains mentioned in the text. Colored arrows show the projections of migration chains on the Ax axis respectively Figure $3 \mathrm{~b}$ and $4 \mathrm{~b}$. The sidebars illustrate areas of large earthquake swarms of higher temporal resolution. 
The diagram in Figure $6 \mathrm{c}$ for zone IIIb (Figure 3b, 4b), besides the chains propagating from the Amut-area swarm (1979-1981) at a velocity of about $30 \mathrm{~km}$ per year to the area of the Ulyugna cluster generation (2003) in the period 1980-1987, exhibits well-ordered earthquake series with a length of up to $60 \mathrm{~km}$ (blue arrows in Figure 4b, 6c), propagating at a velocity of 20-50 km per year from the Kitchera-area swarm (1999) to the Kumora cluster area (2003) (Table 5) and further. Shorter differently directed chains are also visible within the Kitchera-area swarm.

In the diagram in Figure 6d for zone IVb (Figure 3b, 4b), swarm-earthquake activity in the 1979-1983 Angarakan area (two events with $\mathrm{M}_{\max }=4.4$ ) as well as in the area of the Upper Muya earthquake sequence recorded since 2014, are projected on the same spatial-axis segment (violet arrows in Figure 4b, 6d). Intense rupturing observed southwest of the Angarakan swarm involves differently directed migration chains with a length of up to $55 \mathrm{~km}$ and velocity from 15 to $30 \mathrm{~km}$ per year (Table 5).

In the Figure 6e for zone $\mathrm{Vb}$ (Figure 3b, 4b), the migration series propagate from the 1969 Baunt-area swarm to the 1973-1974 Tsipikan-area swarm, from which there are also registered migrations propagating to the area of the 1978 Uakit swarm generation (grey arrows in Figure $4 \mathrm{~b}, 6 \mathrm{e}$ ) at a velocity of $10-25 \mathrm{~km}$ per year over a distance of $15-$ $50 \mathrm{~km}$ in the period 1970-1973 (Table 5).

An analysis of the diagrams plotted for the zones oriented along axes $\sigma_{2}$, shows that there are longer series (up to $60 \mathrm{~km}$ ) in this direction relative to direction $\sigma_{3}$. Most of the migration propagation time exceeds 1 year. In NESW direction the migration velocity is on average $10 \mathrm{~km}$ per year less than in the orthogonal strike.

\section{Discussion}

Plotting spatiotemporal diagrams in Figure 5 and 6 corresponding to mutually orthogonal horizontal stress axes shows that migrations are typical for both directions $\sigma_{3}$ and $\sigma_{2}$. Therefore, seismic process propagates both along major rifting structures and general orientation of the NE-SW-striking active fault groups and orthogonally to major faults along the secondary orientation of the NW-SE-striking active fault groups.

The chains registered in the direction of axes $\sigma_{3}$ are faster and shorter than those registered in direction $\sigma_{2}$. The prevailing maximum migration velocity along the axis of $\sigma_{3}$ is $30 \pm 5 \mathrm{~km}$ per year, and along the axis of $\sigma_{2}-50 \pm$ $5 \mathrm{~km}$ per year. The migration length along $\sigma_{3}$ axis is about $10 \mathrm{~km}$ greater, than that along $\sigma_{2}$ axis, the migration velocity along $\sigma_{2}$ is on average 10 (up to 20) km per year greater, than that along $\sigma_{3}$, (Table 5). Formerly, there was observed a relationship between the velocity of seismic migration and velocity of intraplate movement in the region [Novopashina and Sankov, 2018]. The maximum migration velocities are established in the area between the Kitchera and Upper Angara basins, in the southern Barguzin range, and in the area between the Amut and Barguzin basins which corresponds to high present-day horizontal movement rates therein.

Since the regional tectonic stress field is interrelated with the major trends in the plate movement and the rate of crustal block deformation, a high migration velocity in direction $\sigma_{3}$ may be due to the more intensive crustal NW-SE-oriented deformation than the deformation oriented in the NE-SW direction. Shorter chains in the direction of axes $\sigma_{3}$ can be attributed to the elongation of epicentral concentrations along axes $\sigma_{2}$ and, therefore, to a shorter extension of the NW-SE fracture zones across the general strike of the NE-SW-oriented ruptures. The extension of active fault segments comparable to the length of migration chains along $\sigma_{3}$ reaches in average 60 $\mathrm{km}$. Previously study reports the migration occurring in zones being up to $100 \mathrm{~km}$ width [Novopashina and Sankov, 2018]. Since the migration process involves a system of interacting faults at the tectonic stress transfer from one fault to another, the migrations observed along direction $\sigma_{3}$ reflect the process of the deformation front propagation within epicentral concentrations of many interacting faults of the fracture zone rather than along a certain rupture. In this case, seismic events grouped in migration chains, which can occur both on the subparallel faults along the transfer zones and on the NW-SE-striking faults (rose-diagrams in Figure 3). The transfer zones [Tevelev and Fedorovsky, 2017] stand out in the epicentral field as linear structures striking in the NW-SE orientation across the main NE-SW strike of seismic gaps. On the studied area near the Upper Angara basin, in the epicentral field, the transverse zones on the northeastern closure of the basin and the Akuli-Koter zone, traced in the Upper Angara basin slopes, were identified, (Figure 4), that implies the existence of the fault zone beneath its cover [Sherman et al., 1984]. All the rose-diagrams in Figure 3 also show the secondary NW-SE-striking faults consistent with the direction of the inferred transfer zones. 


\section{Anna V. Novopashina et al.}

\section{Conclusions}

In order to relate geodynamic forces in the northeastern BRZ, producing crustal deformations, to the direction of seismic migration, the seismic-data projection areas have been oriented in the main directions of the principal horizontal stress axes. We have identified the features of activity of seismic migration along the principal horizontal stress axes consistent with the strike of major rifting structures and a general direction of active faults.

The migration propagation was identified in the mutually orthogonal directions at velocities from a few tens of kilometers to $50 \pm 5$ kilometers per year in the high-rate tectonic deformation areas. The migration chains observed NW - SE have a shorter length, shorter time, and a greater velocity than those propagating NE-SW. The difference about $10 \mathrm{~km}$ in chain lengths is due to the fault network configuration in which the NE - SW-striking fault zones are longer than the NW - SE-striking faults. The difference in migration velocities in the orthogonal directions, reaching $20 \mathrm{~km}$ per year, can be attributed to the differences in the deformation process in sub-perpendicular directions.

The results of the spatiotemporal analysis may provide the basis for seismic zoning of the BRS to identify regions of large-earthquake and earthquake-swarm generation and deformation propagation areas.

Data and sharing resources. The seismic data used in the work were obtained with large-scale research facilities «Seismic infrasound array for monitoring Arctic cryolitozone and continuous seismic monitoring of the Russian Federation, neighbouring territories and the world» by the Baikal Regional Seismological Center of the Geophysical Survey RAS (BRSC GS RAS), and partially can be requested at this address: http://seis-bykl.ru/. Plots were made using the MathGL free software version 3.0 (https://sourceforge.net/projects/mathgl,2019).

Acknowledgements. The authors are thankful to colleagues from the Geophysical Survey of the Russian Academy of Sciences for providing complete catalogs of earthquakes of the study area, to sector Editor Paola Montone, Editor Anna Grazia Chiodetti, Editors and Reviewers of Annals of Geophysics Journal for remarks, valuable ideas on improving the article and proof.

This work involved the South Baikal instrumental complex for monitoring hazardous geodynamic processes in frame of the Centre of Geodynamics and Geochronology at the Institute of the Earth's Crust, Siberian Branch of the Russian Academy of Sciences (grant №075-15-2021-682).

\section{References}

Bornyakov, S.A., K.Z. Seminsky, V.Y., Buddo, A.I. Miroshnichenko, A.V. Cheremnykh, A.S. Cheremnykh, and A.A. Tarasova (2014). Main regularities of faulting in lithosphere and their application (based on physical modelling results), Geodyn. Tectonophys., 5, 4, 823-861. (in Russian).

Bykov, V.G. (2018). Prediction and observation of strain waves in the Earth. Geodyn. Tectonophys., 9, 3, $721-754$.

Bykov, V.G. and T.V. Merkulova (2020). Earthquake Migration and Hidden Faults in the Priamurye Region, Russ. J. Pacific Geol., 14, 326-339.

Chéry, J., S. Merkel and S. Bouissou (2001). A physical basis for time clustering of large earthquakes, Bull. Seismol. Soc. Am., 91, 6, 1685-1693.

Dembelov, M.G., O.F. Lukhneva and A.V. Lukhnev (2018). Determination of tropospheric refraction over observation points IRKM (Irkutsk), ULAZ (Ulan-Ude) and BADG (Badary), Geodyn. Tectonophys., 9, 4, 1205-1215. (in Russian).

Gileva, N.A., V.I. Melnikova and Ya.B. Radziminovich (2013). The Tompudinsky earthquake July 4, 2007 with $\mathrm{KP}=14.2, \mathrm{Mw}=5.4, \mathrm{I}_{0}=7-8$ (Northern Baikal region), Earthquakes of Northern Eurasia, 2007, 362-372. (in Russian).

Gorbunova, E.A. and S.I. Sherman (2012). Slow deformation waves in the lithosphere: registration, parameters, and geodynamic analysis (Central Asia), Russ. J. Pacific. Geol., 6, 1, 13-20.

Grapes, R.H. and G.R. Holdgateb (2014). Earthquake clustering and possible fault interactions across Cook Strait, New Zealand, during the 1848 and 1855 earthquakes, New Zealand J. Geol. Geophys., 57, 3, 312-330. 
Jolivet, M., S. Arzhannikov, A. Chauvet, A. Arzhannikova, R. Vassallo, N. Kulagina and V. Akulova (2013). Accommodating large-scale intracontinental extension and compression in a single stress-field: A key example from the Baikal Rift System, Gondwana Res., 24, 3-4, 918-935.

Kanamori H. (1977). The energy release in great earthquakes, J. Geophys. Res., 82, 20, 2981-2987.

Kakourova, A.A. and A.V. Klyuchevskii (2017). Simulation base model of migration seismicity: fault zone, Proceedings of Irkutsk State Technical University, 21, 6, 49-59. (in Russian).

Klyuchevskii, A.V. and A.A. Kakourova (2018). The Main Criteria for Allocating Earthquake Chains in the Baikal Region Lithosphere, Proceedings of Irkutsk State Technical University, 23, 64-73. (in Russian).

Levina, E.A. and V.V. Ruzhich (2015). The seismicity migration study based on space-time diagrams, Geodyn. Tectonoph., 6, 2, 225-244. (in Russian).

Lin, J. and R.S. Stein (2004). Stress triggering in thrust and subduction earthquakes and stress interaction between the southern San Andreas and nearby thrust and strike-slip faults, J. Geophys. Res., 109, B2, B02303.

Logachev, N.A. (2003). History and geodynamics of the Baikal rift, Rus. Geol. Geophys., 5, 373-387.

Logatchev, N.A. (1984). The Baikal Rift System, Episodes, 7, 1, 38-42.

Lukhnev, A.V., V.A. San'kov, A.I. Miroshnichenko, S.V. Ashurkov and E. Calais (2010). GPS rotation and strain rates in the Baikal-Mongolia region, Rus. Geol. Geophys., 51, 7, 785-793.

Lukhnev, A.V., V.A. San'kov, A.I. Miroshnichenko, L.M. Byzov, A.V. San'kov, Yu.B. Bashkuev, Dembelov, M.G. and E. Calais (2013). GPS-measurements of recent crustal deformation in the junction zone of the rift segments in the central Baikal rift system, Rus. Geol. Geophys., 54, 11, 1417-1426.

Lukhneva, O.F., M.G. Dembelov and A.V. Lukhnev (2016). The determination of atmospheric water content from meteorological and GPS data, Geodyn. Tectonophys., 7, 4, 545-553. (in Russian).

Lunina, O.V. (2016). The digital map of the Pliocene-quaternary crustal faults in the southern east Siberia and the adjacent northern Mongolia, Geodyn. Tectonophys., 7, 3, 407-434. (in Russian).

Mats, V.D. (2012). The sedimentary fill of the Baikal basin: implications for rifting age and geodynamics, Rus. Geol. Geophys., 9, 936-954.

Melnikova, V.I., N.A. Radziminovich, A.V. Chipizubov, A.A. Dobrynina and N.A. Gileva (2007). Activation of rifting processes in the Northern Cis-Baikal region: A case study of the Kichera earthquake sequence of 1999, Izvestiya, Phys. Solid Earth, 43, 11, 905-921.

Mel'nikova, V.I., A.I. Seredkina and N.A. Gileva (2020). Spatio-temporal patterns of the development of strong seismic activations (1999-2007) in the northern Baikal area, Rus. Geol. Geophys., 61(1), 96-109.

Misharina, L.A., N.V. Solonenko and L.R. Leontyeva (1975). Local tectonic stresses in the Baikal rift zone according to observations of groups of weak earthquakes, Baikal rift. In: N.A. Florensov, eds., Nauka, Novosibirsk, 5-9. (in Russian).

Mordvinova, V.V., M.M. Kobelev, A.V. Treussov, M.A. Khritova, D.S. Trynkova, E.A. Kobeleva, and O.F. Lukhneva (2016). Deep structure of the Siberian platform - Central Asian mobile belt transition zone from teleseismic data, Geodyn. Tectonophys., 7, 1, 85-103. (in Russian).

Nikolaev, V.V., V.I. Solonenko and S.D. Hil'ko (1975). The evolution of the rift process in the north-east of the Baikal zone. Baikal rift. In: N.A. Florensov, eds., Nauka, Novosibirsk, 55-59. (in Russian).

Novopashnina, A.V. and V.A. San'kov (2015). Migration of seismic activity in strike-slip zones: A case study of the boundary between the North American and Pacific plates. Rus. J. Pacific Geol., 9, 2, 141-153.

Novopashina, A.V. and V.A. Sankov (2018). Migrations of released seismic energy in various geodynamic conditions. Geodyn. Tectonophys., 9, 1, 139-163. (in Russian).

Novopashina, A.V. and E.A. Kuz'mina (2019). Influence of crustal fracturing on the thermal springs and earthquake swarms distribution in the north-east part of the Baikal rift system (Russia), Acque Sotterranee - Italian Journal of Groundwater, 8, 2, 23-36.

Novopashina, A.V. and O.F. Lukhneva (2020). Methodical approach to isolation of seismic activity migration episodes of the northeastern Baikal rift system (Russia), Episodes, 43, 4, 947-959.

Petit, C. and J. Déverchère (2006). Structure and evolution of the Baikal rift: a synthesis, Geochem. Geophys. Geosys., 7, 11, Q11016.

Petit, C., J. Déverchère, F. Houdry, V.A. Sankov, V.I. Melnikova, and D. Delvaux (1996). Present day stress field changes along the Baikal rift and tectonic implications, Tectonics, 15, 6, 1171-1191.

Petit, C., E. Burov and Ch. Tiberi, (2008). Strength of the lithosphere and strain localization in the Baikal rift, Earth 


\section{Anna V. Novopashina et al.}

Planet. Sci. Lett., 269, 522-528.

Pollitz, F., M. Vergnolle and E. Calais (2003). Fault interaction and stress triggering of twentieth century earthquakes in Mongolia, J. Geophys. Res.: Solid Earth, 108, B10, 2503.

Radziminovich, N.A. (2010). Focal depths of earthquakes in the Baikal region: A review, Izvestiya Phys. Solid Earth, 46, 3, 216-229.

Radziminovich, N.A., N.A. Gileva, V.I. Melnikova and M.G. Ochkovskaya (2013). Seismicity of the Baikal rift system from regional network observations, J. Asian Earth Sci., 62, 146-161.

Radziminovich, N.A., N.A. Gileva, Ya.B. Radziminovich, M.G. Kustova, V.V. Chechelnitsky, and V.I. Melnikova (2009). The Kumora earthquake of September 16, 2003 with $\mathrm{Mw}=5.6, \mathrm{Kr}=14.3, \mathrm{I0}=7$ (Baikal rift zone), Earthq. of North. Eurasia, 2003, 293-309. (in Russian).

Richter, E.F., 1958. Elementary Seismology. W.H. Freeman and Co., San Francisco, 768.

Ruzhich, V.V., G.G Kocharyan and E. A. Levina (2016). Estimated geodynamic impact from zones of collision and subduction on the seismotectonic regime in the Baikal rift, Geodyn. Tectonophys., 7, 3, 383-406. (in Russian).

San'kov, V., J. Déverchère, Y. Gaudemer, F. Houdry and A. Filippov (2000). Geometry and rate of faulting in the North Baikal Rift, Siberia, Tectonics, 19, 4, 707-732.

San'kov, V.A., A.V. Parfeevets, A.V. Lukhnev, A.I. Miroshnichenko and S.V. Ashurkov (2011). Late Cenozoic geodynamics and mechanical coupling of crustal and upper mantle deformations in the Mongolia-Siberia mobile area, Geotectonics., 45, 5, 378.

San'kov, V.A. and A.A. Dobrynina (2015). Modern fault formation in the Earth's crust of the Baikal rift system according to the data on the mechanisms of earthquake sources, Dokl. Earth Sci., 465, 1, 1191-1195.

Sherman, S.I., K.G. Levy, V.V., Ruzhich, V.A. Sankov, V.I. Dneprovskiy and S.V. Rasskazov (1984). Geology and seismicity of the BAM zone, Neotectonics. In: N.A. Logatchev, eds., Nauka, Novosibirsk, 356. (in Russian).

Sherman, S.I., K.Zh. Seminsky, S.A. Bornyakov, A.N. Adamovich, R.M. Lobatskaya, S.V. Lysak, and K.G. Levi (1992). Faulting in the Lithosphere. Extensional zones. In: N.A. Logatchev, eds., Nauka, Novosibirsk. 228. (in Russian).

Sherman, S.I. (2013). Deformation waves as a trigger mechanism of seismic activity in seismic zones of the continental lithosphere, Geodyn. Tectonophys., 4, 2, 83-117. (in Russian).

Sherman, S.I. (2014). Seismic Process and the Forecast of Earthquakes: Tectonophysical Conception. In: G.A. Sobolev, Geo, Novosibirsk. 259. (in Russian).

Solonenko, N.V. and A.V. Solonenko (1987). Aftershock sequences and swarms of earthquakes in the Baikal rift zone, In: V.M. Kochetkov, Nauka, Novosibirsk, 89. (in Russian).

Tapponnier, P. and P. Molnar (1979). Active faulting and Cenozoic tectonics of the Tien Shan, Mongolia, and Baykal regions, J. Geophys., Res., 84, 3425-3459.

Tevelev, A.V. and V.S. Fedorovsky (2017). The kinematics of the Baikal rift zone accommodation structures, M. Un. Geol. Bull., 72, 3, 181-191.

Thybo, H. and C.A. Nielsen, (2009). Magma-compensated crustal thinning in continental rift zones, Nature, 457, 7231, 873-876.

Trofimenko, S.V., V.G. Bykov and T.V. Merkulova (2017). Space-time model for migration of weak earthquakes along the northern boundary of the Amurian microplate, J. Seismol., 21, 2, 277-286.

Tung, S. and T. Masterlark (2018). Delayed poroelastic triggering of the 2016 October Visso earthquake by the August Amatrice earthquake, Italy, Geophys. Res. Lett., 45, 5, 2221-2229.

Turutanov, E.H. (2018). The anomalies of gravity, deep structure and geodynamics of the Mongol-Siberian region. In: E.H. Turutanov, eds., IRNITU, Irkutsk, 180. (in Russian).

Vikulin, A.V., K.F. Makhmudov, A.G. Ivanchin, A.I. Gerus and A.A. Dolgaya (2016). On wave and rheidity properties of the Earth's crust, Phys. of the Solid State, 58, 3, 561-571.

Žalohar, J. (2018). The Omega-Theory: A New Physics of Earthquakes (2nd ed.), Elsevier, Amsterdam, Netherlands, 570 .

Zonenshain, L.P. and L.A. Savostin (1981). Geodynamics of Baikal rift zone and plate tectonics of Asia, Tectonophys., 76, 1-2, 1-45.

Zorin, Yu.A., E.Kh. Turutanov, V.V. Mordvinova, V.M. Kozhevnikov, T.B. Yanovskaya, and A.V. Treussov (2003). The Baikal rift zone: the effect of mantle plumes on older structure, Tectonophys., 371, 153-173. 
Velocity of seismic activity migration

*CORRESPONDING AUTHOR: Anna V. NOVOPASHINA,

Institute of the Earth's Crust, Siberian Branch of RAS, Irkutsk 664033,

Russia, e-mail: avn_crust@mail.ru

(c) 2021 the Author(s). All rights reserved.

Open Access. This article is licensed under a Creative Commons Attribution 3.0 International 